Research

\title{
Human receptor kinetics and lung tissue retention of the enhanced-affinity glucocorticoid fluticasone furoate Anagnostis Valotis and Petra Högger*
}

\author{
Address: Universität Würzburg, Institut für Pharmazie und Lebensmittelchemie, Würzburg, Germany \\ Email: Anagnostis Valotis - valotis@pzlc.uni-wuerzburg.de; Petra Högger* - hogger@pzlc.uni-wuerzburg.de \\ * Corresponding author
}

Published: 25 July 2007

Respiratory Research 2007, 8:54 doi:10.1 |86/1465-992I-8-54

This article is available from: http://respiratory-research.com/content/8/1/54

(C) 2007 Valotis and Högger; licensee BioMed Central Ltd.

This is an Open Access article distributed under the terms of the Creative Commons Attribution License (http://creativecommons.org/licenses/by/2.0), which permits unrestricted use, distribution, and reproduction in any medium, provided the original work is properly cited.
Received: 28 August 2006

Accepted: 25 July 2007

\begin{abstract}
Fluticasone furoate (FF) - USAN approved name, a new topically active glucocorticoid has been recently identified. The aim of this study was to characterise the binding affinity of this compound to the human lung glucocorticoid receptor in relation to other glucocorticoids. Additionally, we sought to determine the binding behaviour of fluticasone furoate to human lung tissue. The glucocorticoid receptor binding kinetics of fluticasone furoate revealed a remarkably fast association and a slow dissociation resulting in a relative receptor affinity (RRA) of $2989 \pm 135$ with reference to dexamethasone (RRA: $100 \pm 5$ ). Thus, the RRA of FF exceeds the RRAs of all currently clinically used corticosteroids such as mometasone furoate (MF; RRA 2244), fluticasone propionate (FP; RRA 1775), ciclesonide's active metabolite (RRA 12/2 - rat receptor data) or budesonide (RRA 855). FP and FF displayed pronounced retention in human lung tissue in vitro. Lowest tissue binding was found for MF. There was no indication of instability or chemical modification of FF in human lung tissue. These advantageous binding attributes may contribute to a highly efficacious profile for FF as a topical treatment for inflammatory disorders of the respiratory tract.
\end{abstract}

\section{Background}

A new topically active glucocorticoid, fluticasone furoate (FF, GW685698X), has been recently identified (Figure 1) and is being progressed for the treatment of respiratory diseases. Fluticasone furoate (FF) shares structural similarities with fluticasone propionate (FP) with the exception of the substitution of the 17- $\alpha$ hydroxyl group. While this position is esterified with propionic acid in FP, FF carries a 2-furoate ester moiety.

For topically applied glucocorticoids, it is favorable to combine high local efficacy with low systemic exposure. An enhanced affinity for lung tissue may prolong residence time in the lung and minimise systemic effects. Therefore, a high receptor affinity and a high retention in the target tissue should be paralleled by rapid and complete hepatic metabolism of the glucocorticoid to inactive derivatives. We previously described the receptor binding affinity of FP and MF as well as their retention in lung tissue in vitro [1-4]. Both FP and MF have high affinities for the human lung glucocorticoid receptor. The relative receptor affinity (RRA) of FP is about 1800 compared to the reference compound dexamethasone (RRA=100), the RRA of MF is about 2250.

The aim of this study was to characterise the binding affinity of the novel compound FF to the glucocorticoid receptor in relation to other glucocorticoids. Therefore, we isolated human lung glucocorticoid receptors from human lung tissue and determined the binding affinity of 

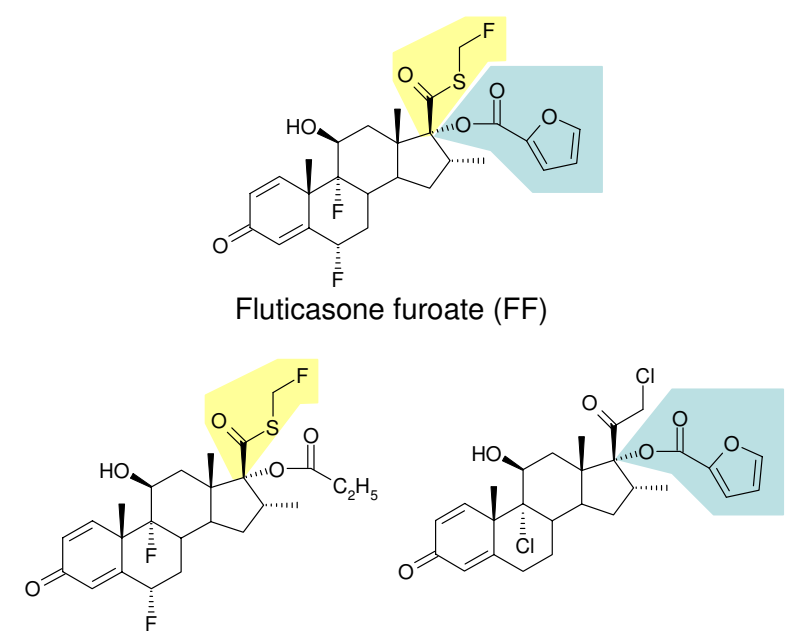

Fluticasone propionate (FP)

Mometasone furoate (MF)

\section{Figure I}

Structural formulae of the new glucocorticoid fluticasone furoate in comparison with fluticasone propionate and mometasone furoate.

these glucocorticoids by the kinetic method described earlier [1]. Additionally, we sought to determine the retention of FF in human lung tissue.

\section{Methods}

\section{Chemicals and reagents}

$\left[{ }^{3} \mathrm{H}\right]$-Dexamethasone was obtained from Amersham (Freiburg, Germany), dexamethasone was purchased from Merck (Darmstadt, Germany). [3 $\left.{ }^{3} \mathrm{H}\right]$-Fluticasone furoate, $\mathrm{FP}, \mathrm{MF}, \mathrm{FF}$, ciclesonide (Cicle) and its active metabolite desisobutyryl-ciclesonide (des-Cicle), beclomethasone-17, 21-dipropionate (BDP) and its metabolite beclomethasone-17-monopropionate (17-BMP) and beclomethasone-21-monopropionate (21-BMP) were generous gifts from GlaxoSmithKline (Greenford, England). The origin of all other glucocorticoids mentioned is described in [5]. Dimethyl-2-2-dichlorvinylphosphate (dichlorvos) was purchased from Riedel de Haën (Seelze, Germany), DL-dithiothreitol (DTT) from Sigma-AldrichChemie (Taufkirchen, Germany). Complete ${ }^{\mathrm{TM}}$ (combination of different protease inhibitors) was obtained from Roche Applied Science (Mannheim, Germany), Norit A from Serva (Heidelberg, Germany). Diethylether (HPLC grade) was purchased from Fluka (Buchs, Switzerland) and acetonitrile (ACN, HPLC gradient grade) from Fisher Scientific, (Schwerte, Germany). Water from a Millipore water purification unit was used. All other chemicals were obtained from E. Merck (Darmstadt, Germany).

\section{Buffer solutions}

Buffer solution G contained $10 \mathrm{mM}$ TRIS, $10 \mathrm{mM}$ $\mathrm{Na}_{2} \mathrm{MoO}_{4}, 30 \mathrm{mM} \mathrm{NaCl}, 10 \%$ glycerol (pH 7.4). Buffer solution A contained $4 \mathrm{mM}$ DTT, $5 \mathrm{mM}$ dichlorvos and 1 $\mathrm{mM}$ Complete $^{\mathrm{TM}}$ in $100 \mathrm{~mL}$ buffer solution G. KrebsRinger-HEPES buffer ( $\mathrm{pH} 7.4$ ) consisted of $118 \mathrm{mM} \mathrm{NaCl}$, $4.84 \mathrm{mM} \mathrm{KCl}, 1.2 \mathrm{mM} \mathrm{KH}{ }_{2} \mathrm{PO}_{4}, 2.43 \mathrm{mM} \mathrm{MgSO}_{4}, 2.44$ $\mathrm{mM} \mathrm{CaCl}{ }_{2} \times 2 \mathrm{H}_{2} \mathrm{O}$ and $10 \mathrm{mM}$ HEPES.

\section{Source and handling of human specimen}

Human lung tissue resection material was obtained from patients with bronchial carcinomas who gave informed consent. Cancer-free tissue was used for the experiments. None of the patients was treated with glucocorticoids for the last 4 weeks prior to surgery. Tissue samples were used immediately for tissue metabolism studies to retain full enzymatic activity. For other experiments, tissue samples were shock frozen in liquid nitrogen after resection and stored at $-70^{\circ} \mathrm{C}$ until usage. To collect sufficient material for the experiments tissue samples of three or more patients were pooled.

Plasma samples were obtained from healthy volunteers who gave informed consent. Samples were used immediately for metabolism studies to retain full enzymatic activity. For desorption and other experiments, plasma samples were shock frozen in liquid nitrogen and stored at $-70^{\circ} \mathrm{C}$ until usage.

\section{Preparation of lung cytosol for receptor binding experiments}

Human lung tissue was deep frozen immediately after resection and stored in liquid nitrogen. Frozen tissue was pulverized and homogenized in three aliquots buffer solution A with an Ultra Turrax mixer (Janke and Kunkel, Staufen, Germany) in an ice bath. Thereafter the diluted cytosol was centrifuged for $1 \mathrm{hr}$ at $105,000 \times \mathrm{g}$ at $4^{\circ} \mathrm{C}$ (Ultracentrifuge L8-55 M, Beckman Instruments Irvine, California). The cytosol was stored in aliquots at $-70^{\circ} \mathrm{C}$. The protein concentration of the cytosol was determined according to the method of Lowry et al. [6]. Concentration of glucocorticoid receptors in the cytosol was 30-60 $\mathrm{fmol} / \mathrm{mg}$ protein.

\section{Kinetics of receptor binding of glucocortiocids}

The receptor binding experiments were performed according to the procedure described earlier [1] based on [7-9].

A. Determination of receptor number in the cytosol and calculation of equilibrium dissociation rate constant

Various dilutions of $\left[{ }^{3} \mathrm{H}\right]$-dexamethasone in buffer solution $\mathrm{G}\left(6 \times 10^{-7}\right.$ to $\left.1.2 \times 10^{-8} \mathrm{~mol} / \mathrm{L}\right)$ were prepared. For elucidation of non-specific binding a solution of dexamethasone $\left(1.2 \times 10^{-5} \mathrm{~mol} / \mathrm{L}\right)$ in buffer solution $\mathrm{G}$ was used. For the assay of non-specific binding $\left(\mathrm{B}_{\mathrm{ns}}\right.$ in $\left.[\mathrm{mol} / \mathrm{L}]\right), 20$ 
$\mu \mathrm{L}$ of $\left[{ }^{3} \mathrm{H}\right]$-dexamethasone and $20 \mu \mathrm{L}$ of the unlabelled compound were added to $200 \mu \mathrm{L}$ of cytosol, were mixed in glass vials and incubated for 18 to $20 \mathrm{~h}$ at $0-4{ }^{\circ} \mathrm{C}$. The assay for total binding $\left(\mathrm{B}_{\mathrm{t}}\right.$ in $\left.[\mathrm{mol} / \mathrm{L}]\right)$ was carried out accordingly, but the unlabelled glucocorticoid was replaced by buffer solution $\mathrm{G}$. To determine the total $\left[{ }^{3} \mathrm{H}\right]-$ glucocorticoid concentration (T), $20 \mu \mathrm{L}$ of the mixture were used for scintillation counting. After incubation, 200 $\mu \mathrm{L}$ of each incubation mixture were added to $200 \mu \mathrm{L}$ suspension of activated charcoal ( $2 \%$ Norit A in buffer solution $\mathrm{G}$ ), incubated for $10 \mathrm{~min}$ on ice and centrifuged for 5 min between $0-4^{\circ} \mathrm{C}$. For scintillation counting $200 \mu \mathrm{L}$ of the supernatant were used. Scintillation counting was performed with a Rackbeta 1214 LKB from Wallac (Freiburg, Germany) using Emulsifier-Safe ${ }^{\mathrm{TM}}$ from Packard Bioscience (Groningen, Netherlands).

Receptor concentration $\left(\mathrm{R}_{0}\right)$ of the cytosol was calculated by the method of Scatchard [10] according the equation:

$$
\frac{\left[B_{s}\right]}{[H]}=\frac{\left[R_{0}\right]}{K_{D}}-\frac{\left[B_{s}\right]}{K_{D}}
$$

with $\mathrm{B}_{\mathrm{S}}$ being the specific binding of the labelled dexamethasone in $[\mathrm{mol} / \mathrm{L}], \mathrm{H}$ being the unbound labelled glucocorticoid, and $\mathrm{K}_{\mathrm{D}}$ being the equilibrium dissociation rate constant. $\mathrm{B}_{\mathrm{S}}$ and $\mathrm{H}$ were indirectly determined using the equations:

$$
\begin{gathered}
{\left[B_{s}\right]=\left[B_{t}\right]-\left[B_{n s}\right]} \\
{[H]=[T]-\left[B_{t}\right]}
\end{gathered}
$$

The Scatchard plot revealed the equilibrium dissociation rate constant $\mathrm{K}_{\mathrm{D}}$ (slope of the straight line) and the receptor number $\mathrm{R}_{0}$ in mol receptors per $\mathrm{mg}$ total protein of the cytosol (interception of the straight line with the $\mathrm{x}$-axis).

\section{B. Determination of association rate constants $k_{\text {Ass }}\left(=k_{l}\right)$}

For the determination of the association rate constant, the cytosol was incubated with different concentrations of $\left[{ }^{3} \mathrm{H}\right]$-glucocorticoid in the absence and presence of excess unlabelled glucocorticoid. For the assay of non-specific binding, 10 parts of cytosol, 1 volume part of $\left[{ }^{3} \mathrm{H}\right]$-glucocorticoid $\left(1.2 \times 10^{-7} \mathrm{~mol} / \mathrm{L}\right)$ and 1 volume part of cold glucocorticoid $\left(1.2 \times 10^{-4} \mathrm{~mol} / \mathrm{L}\right)$ were mixed in glass vials and incubated at $20^{\circ} \mathrm{C}$. The assay for total binding was carried out accordingly, but the unlabelled glucocorticoid $\left(1.2 \times 10^{-4} \mathrm{~mol} / \mathrm{L}\right)$ was replaced by buffer $\mathrm{G}$. To determine the total $\left[{ }^{3} \mathrm{H}\right]$-glucocorticoid concentration, aliquots of the incubation mixtures were used for scintillation counting. At intervals, $200 \mu \mathrm{L}$ incubation mixture were mixed with $200 \mu \mathrm{L}$ suspension of Norit A, incubated for $10 \mathrm{~min}$ on ice and centrifuged for $5 \mathrm{~min}$ between $0-4{ }^{\circ} \mathrm{C}$. For scintillation counting $200 \mu \mathrm{L}$ of the supernatant were used.
The association rate constant $\left(\mathrm{k}_{\mathrm{Ass}}=\mathrm{k}_{1}\right)$ of the cytosol was calculated according the equation:

$$
Z_{t}=\frac{\ln \left(\left[G_{t}\right] /\left[R_{t}\right]\right)}{\left[G_{0}\right]-\left[R_{0}\right]}=K_{A S S} \cdot t+\frac{\ln \left(\left[G_{0}\right] /\left[R_{0}\right]\right)}{\left[G_{0}\right]-\left[R_{0}\right]}
$$

with $\mathrm{G}_{\mathrm{t}}$ being the concentration of unbound labelled glucocorticoid at time $t, R_{t}$ being the concentration of free receptors at time $t, G_{0}$ being the concentration of unbound labelled glucocorticoid at time $t=0, R_{0}$ being the concentration of free receptors at time $t=0$ and $t$ being the time of incubation. $G_{0}$ and $G_{t}$ were indirectly determined using the equations:

$$
\left[G_{0}\right]=[T]-\left[B_{n s, 0}\right] \text { and }\left[G_{t}\right]=[T]-\left[B_{n s, t}\right]
$$

To linearize the calculated data points a $Z_{\mathrm{t}}$-value was calculated for each time point of measurement taking the dilution factor of the cytosol and the receptor concentration into account:

$$
Z_{t}=\frac{\ln \left\{\left([T]-\left[B_{n s, t}\right]\right) /\left(\left[R_{0}\right]-\left[B_{T, t}\right]+\left[B_{n s, t}\right]\right)\right\}}{[T]-\left[B_{n s, t}\right]-\left[R_{0}\right]}
$$

The $\mathrm{Z}_{\mathrm{t}}$-values were plotted against time $\mathrm{t}$ and a linear regression was performed. The slope of the straight line $\left(\mathrm{k}_{\mathrm{Ass}}=\mathrm{k}_{1}\right)$ and the coefficient of correlation $\mathrm{r}$ were calculated based on a minimum of four data points. The coefficient of correlation was always higher than $r=0.975$.

C. Determination of dissociation rate constants $k_{\text {Diss }}\left(=k_{-1}\right)$ For determination of the dissociation rate constant, 10 volume parts cytosol and 1 volume part $\left[{ }^{3} \mathrm{H}\right]$-glucocorticoid solution $\left(6 \times 10^{-7} \mathrm{~mol} / \mathrm{L}\right)$ were incubated for $18-20$ $\mathrm{h}$ between $0-4{ }^{\circ} \mathrm{C}$ (mixture 1 ). To determine the non-specific binding, 10 volume parts of cytosol, 1 volume part of $\left[{ }^{3} \mathrm{H}\right]$-glucocorticoid solution $\left(6 \times 10^{-7} \mathrm{~mol} / \mathrm{L}\right)$ and 1 part of unlabelled glucocorticoid $\left(3 \times 10^{-4} \mathrm{~mol} / \mathrm{L}\right)$ were incubated for $18-20 \mathrm{~h}$ between $0-4{ }^{\circ} \mathrm{C}$ (mixture 2 ). Incubation mixtures were subsequently brought to a temperature of $20^{\circ} \mathrm{C}$. One volume part of unlabelled glucocorticoid ( 3 $\times 10^{-4} \mathrm{~mol} / \mathrm{L}$ ) was added to mixture 1 . At intervals $200 \mu \mathrm{L}$ each of the mixtures 1 and 2 were mixed with $200 \mu \mathrm{L}$ Norit A suspension, incubated at $0-4{ }^{\circ} \mathrm{C}$ for $10 \mathrm{~min}$ and thereafter centrifuged for $5 \mathrm{~min}$ at $0-4^{\circ} \mathrm{C}$. The supernatant was used for scintillation counting. The first order rate constant was calculated according:

$$
\left[B_{s, t}\right]=\left[B_{s, 0}\right] \cdot e^{-K_{\text {Diss }} \cdot t}
$$

with $B_{s, t}$ being the specific binding of the labelled compound at time $\mathrm{t}, \mathrm{B}_{\mathrm{s}, 0}$ being the specific binding of the labelled compound at time $t=0$. Since the specific bind- 
ing was determined indirectly (see A) the equation can be rewritten as:

$$
\left[B_{T, t}\right]-\left[B_{n s, t}\right]=\left(\left[B_{T, 0}\right]-\left[B_{n s, t}\right]\right) \cdot e^{-K_{D i s s} \cdot t}
$$

The $B_{s, t}$-values were plotted semi-logarithmical against time $t$ and a linear regression was performed. The slope of the straight line $\left(\mathrm{k}_{\text {Diss }}=\mathrm{k}_{-1}\right)$ and the coefficient of correlation $r$ were calculated based on a minimum of six data points. The coefficient of correlation was always higher than $\mathrm{r}=0.975$.

Equilibrium dissociation constant $\left(\mathrm{K}_{\mathrm{D}}\right)$ was calculated for each glucocorticoid based on association and dissociation rate constants:

$$
K_{D}=\frac{k_{-1}}{k_{1}}
$$

Relative receptor affinities (RRA) for glucocorticoids (GC) were calculated with reference to dexamethasone (Dexa):

$$
R R A=\frac{K_{D} \text { Dexa }}{K_{D} G C} \times 100
$$

\section{Stability of fluticasone furoate (FF) in fresh human lung tissue in vitro}

Fluticasone furoate (FF) $(0.3 \mu \mathrm{g} / \mathrm{mL})$ was incubated in 10 $\mathrm{ml}$ Krebs-Ringer-HEPES buffer with lung tissue pieces at $37^{\circ} \mathrm{C}$ shielded from light in a thermostatically controlled shaking water bath GFL 1083 (Burgwedel, Germany). Incubations were performed in the presence and absence of dichlorvos $(1 \mathrm{mg} / \mathrm{mL})$. Over 24 hours, samples of 1.0 $\mathrm{mL}$ tissue-free supernatant were taken and immediately stored at $-20^{\circ} \mathrm{C}$ until analysis. The incubation medium was replenished by buffer which was pre-temperated to $37^{\circ} \mathrm{C}$. In case of incubations with dichlorvos the medium used for replenishment contained the esterase inhibitor.

\section{Adsorption of glucocorticoids to lung tissue}

Lung tissue was washed in Krebs-Ringer-HEPES buffer (pH 7.4) and sliced into pieces of $1 \mathrm{~mm}^{3}$. For each binding experiment approximately $0.5 \mathrm{~g}$ of lung tissue was used. Adsorption of glucocorticoids $(0.3 \mu \mathrm{g} / \mathrm{mL})$ to human lung tissue was determined as described earlier [3]. Briefly, lung tissue pieces were suspended under gentle shaking for $1 \mathrm{~h}$ at $37^{\circ} \mathrm{C}$ in $20 \mathrm{ml}$ Krebs-Ringer-HEPES buffer containing $0.3 \mu \mathrm{g} / \mathrm{ml}$ of the glucocorticoid. $2.0 \mathrm{~mL}$ samples were taken and stored at $-20^{\circ} \mathrm{C}$ until analysis. The volume withdrawn was replaced with fresh buffer of $37^{\circ} \mathrm{C}$. Only glass lab ware was used for these experiments to avoid any non-specific binding effects of the highly lipophilic compounds to plastic material. For control, blank samples with glucocorticoid-containing buffer, but no tissue, were incubated under the same experimental conditions ( $1 \mathrm{~h}$ at $37^{\circ} \mathrm{C}$, in Krebs-Ringer-HEPES buffer) and analyzed for non-specific adsorption of the glucocorticoids to the glass tubes.

\section{Desorption of glucocorticoids from lung tissue}

Desorption of glucocorticoids to human lung tissue was determined as described earlier [3]. Briefly, lung tissue $(1.0 \mathrm{~g})$ was saturated with glucocorticoids for $1 \mathrm{~h}$ at $37^{\circ} \mathrm{C}$ by shaking in $40 \mathrm{~mL}$ Krebs-Ringer-HEPES buffer containing $0.3 \mu \mathrm{g} / \mathrm{mL}$ of the respective glucocorticoid. After incubation tissue was washed with $2 \mathrm{~mL}$ buffer and transferred into $10.0 \mathrm{~mL}$ human plasma $\left(37^{\circ} \mathrm{C}\right)$. Again, only glass lab ware was used for these experiments to exclude any nonspecific binding effects of the highly lipophilic compounds to plastic material. Samples of $1.0 \mathrm{~mL}$ were taken at defined time points. The volume was replaced with fresh plasma at $37^{\circ} \mathrm{C}$. Samples were stored at $-20^{\circ} \mathrm{C}$ until further analysis.

\section{Sample preparation, HPLC conditions and data analysis}

Samples of $1.0 \mathrm{~mL}$ (tissue desorption/stability) or $2.0 \mathrm{~mL}$ (tissue adsorption) were mixed with $0.1 \mathrm{~mL}$ internal standard solution and extracted twice with $3 \mathrm{~mL}$ diethylether for $30 \mathrm{~min}$, using a roller mixer, followed by centrifugation $\left(20^{\circ} \mathrm{C}\right)$ for $5 \mathrm{~min}$. The organic phase was separated and evaporated to dryness under a gentle stream of nitrogen at $25^{\circ} \mathrm{C}$. The resulting residue was reconstituted in $0.2 \mathrm{~mL}$ mobile phase. Internal standard (IS) was amcinonide $3 \mu \mathrm{g} / \mathrm{mL}$ (tissue binding studies) or dexamethasone $3 \mu \mathrm{g} / \mathrm{mL}$ (stability studies). Linearity was given from $10-500 \mathrm{ng} / \mathrm{mL}$ glucocorticoid, coefficients of correlation of the calibration curves were at least 0.99.

The HPLC system was a Waters HPLC (Milford, MA) consisting of a 1525 binary pump, an 717plus autosampler and 2487 dual wavelength absorbance detector set at the detection wavelength of $254 \mathrm{~nm}$. Data collection and integration were accomplished using Breeze ${ }^{\mathrm{TM}}$ software version 3.2. Analysis was performed on a Symmetry $\mathrm{C}_{18}$ column $(150 \times 4.6 \mathrm{~mm}$ I.D., $5 \mu \mathrm{m}$ particle size, Waters, MA). Typically, $20 \mu \mathrm{L}$ of sample were injected and separated at a flow rate of $1 \mathrm{~mL} / \mathrm{min}$. Gradient elution was performed using water (containing $0.2 \%(\mathrm{v} / \mathrm{v})$ acetic acid) and ACN, starting at $60: 40(\mathrm{v} / \mathrm{v})$ water/ACN increasing linearly to $29: 71(\mathrm{v} / \mathrm{v})$ water/ACN by $30 \mathrm{~min}$. The assay was accurate and reproducible. The lower limit of quantitation was $10 \mathrm{ng} / \mathrm{mL}$ for all glucocorticoids except ciclesonide $(20 \mathrm{ng} / \mathrm{mL})$.

\section{Determination of the relative retention time $\boldsymbol{k}^{\prime}$ of glucocorticoids}

Relative retention times $\mathrm{k}^{\prime}$ or chromatographic capacity factors $\log \left(\mathrm{k}^{\prime}\right)$, respectively, of all new generation glucocorticoids in comparison with older glucocorticoids were determined by a HPLC method based on a former report 
[5]. Briefly, to calculate $\mathrm{k}^{\prime}$ the HPLC retention time on a $\mathrm{C}_{18}$ reversed-phase column of an individual glucocorticoid was related to the retention time of an internal standard (dexamethasone-21-isonicotinate). Therefore, $10 \mu \mathrm{L}$ of the respective glucococorticoid and the internal standard at a concentration of each $10 \mu \mathrm{g} / \mathrm{mL}$ in methanol were chromatographed under identical conditions (column and HPLC system described above). The sample was injected and separated at a flow rate of $0.7 \mathrm{~mL} / \mathrm{min}$. The mobile phase consisted of methanol, water, ACN and acetic acid at 40:20:5:0.2 (v/v).

\section{Statistical analysis}

Mean and mean deviation of the mean were calculated for all data. Data sets were analysed by one-way ANOVA with post-hoc Bonferroni's multiple comparison test. Statistical significance was defined as a significance level of $\mathrm{p} \leq 0.05$. Due to the very limited sample number a pre-test was performed to test the normal distribution of the residuals. Therefore, the residuals of each data group were calculated and the ratio of range to standard deviation was analysed according to David et al. [11]. Only when the results were between the lower and upper critical limits tabulated by Pearson and Stephens [12] a normal distribution of the residuals was assumed at a significance level of $p \leq 0.05$ and a subsequent ANOVA analysis was performed. On one data set a reciprocal transformation was performed for normal distribution of the residuals and subsequent ANOVA analysis. Due to the limited number of data p values should be interpreted very cautiously.

\section{Results}

Receptor binding kinetics and relative receptor affinity of fluticasone furoate (FF)

The receptor binding kinetics to the human lung glucocorticoid receptor revealed that the association kinetics of fluticasone furoate $(\mathrm{FF})$ was distinctly different from those of fluticasone propionate (FP) and mometasone furoate (MF) (Table 1). The association rate constant of FF was statistically significantly higher compared to both MF and FP (both $\mathrm{p} \leq 0.001$ ); thus the specific binding to the recep- tor occurred more rapidly and to a higher extent compared with all other glucocorticoids. In contrast, the dissociation rate constant of FF was comparable with that of FP and MF with no statistically significant difference. Consequently, the calculated half-lives of the glucocorticoid-receptor complexes $\left(t_{1 / 2}\right)$ of FF, FP and MF were all around 10 hours. Equilibrium dissociation rate constants $\left(k_{d}\right)$ were derived from the association and dissociation rate constants. The calculated $\mathrm{k}_{\mathrm{d}}$ of FF was $0.30 \mathrm{nmol} / \mathrm{L}$, the lowest among the tested glucocorticoids (statistically significantly lower compared to $\mathrm{FP}, \mathrm{p} \leq 0.001$, and to MF, $\mathrm{p} \leq 0.05$ ). The $\mathrm{k}_{\mathrm{d}}$ of FP was $0.51 \mathrm{nmol} / \mathrm{L}$, the $\mathrm{k}_{\mathrm{d}}$ of MF was determined as $0.41 \mathrm{nmol} / \mathrm{L}$ (statistically significantly different, $\mathrm{p} \leq \mathrm{0.05}$ ). Based on the equilibrium dissociation rate constants the relative receptor affinity (RRA) of FF was calculated as $2989 \pm 135$. This RRA of FF was significantly higher compared to FP, $\mathrm{p} \leq 0.001$, and to $\mathrm{MF}, \mathrm{p} \leq 0.05$.

\section{Correlation between glucocorticoid lipophilicy and receptor affinity}

The chromatographic capacity factor $\log \left(\mathrm{k}^{\prime}\right)$ reveals an excellent correlation to the partition coefficient in 1-octanol-water $[13,14]$ which is regarded as a typical parameter of compound lipophilicity. When the lipophilicity of a glucocorticoid is expressed as its relative retention time $\mathrm{k}^{\prime}$ at a reversed-phase HPLC column and correlated with the relative receptor affinity of the respective compound, a significant relationship is observed (Figure 2). Potential fitting of the data according to the equation: $y=c^{*} x^{b}$. (with $\mathrm{c}$ and $\mathrm{b}$ representing constants) revealed a coefficient of correlation of $r=0.982$. This relationship is statistically significant $(\mathrm{p}<0.0001)$. All glucocorticoids esterified at C21 display higher lipophilicity. However, these compounds have little or no binding affinity to the glucocorticoid receptor. They are either inactive metabolites such as beclomethasone-21-monopropionate (21BMP) or inactive pro-drugs such as ciclesonide or beclomethasone-17,21-dipropionate which need to be activated by hydrolysis of the C21 ester $[15,16]$.

Table I: Results of the kinetic binding experiments of dexamethasone (Dexa), fluticasone furoate (FF), fluticasone propionate (FP) and mometasone furoate (MF) to the human lung glucocorticoid receptor. Values given represent mean and mean deviation of the mean of three to seven experiments. Binding data of FP and MF are from our previous experiments (Ref. [3]).

\begin{tabular}{cccccc}
\hline Glucocorticoid & $\mathrm{k}_{1} \times 10^{5}(\mathrm{~L} /[\mathrm{mol} / \mathrm{min}])$ & $\mathrm{k}_{-1} \times 10^{-4}[\mathrm{l} / \mathrm{min}]$ & $\mathrm{K}_{\mathrm{D}}[\mathrm{nmol} / \mathrm{L}]$ & $\mathrm{t}_{\mathrm{I} / 2}[\mathrm{~h}]$ & $\mathrm{RRA}$ \\
\hline Dexa & $10.53 \pm 0.35$ & $94.67 \pm 5.43$ & $8.80 \pm 0.41$ & $1.23 \pm 0.04$ & $100 \pm 5$ \\
FF & $\mathbf{3 7 . 4 6} \pm \mathbf{0 . 7 3}$ & $11.22 \pm \mathbf{0 . 6 2}$ & $\mathbf{0 . 3 0 \pm 0 . 0 2}$ & $1 \mathbf{0 . 3 4} \pm \mathbf{0 . 5 9}$ & $\mathbf{2 9 8 9} \pm 135$ \\
FP & $21.17 \pm 0.56$ & $10.73 \pm 0.65$ & $0.51 \pm 0.03$ & $10.82 \pm 0.64$ & $1775 \pm 130$ \\
MF & $29.46 \pm 1.10$ & $11.82 \pm 0.31$ & $0.41 \pm 0.03$ & $9.83 \pm 0.53$ & $2244 \pm 142$
\end{tabular}

Statistically significant differences were observed in the association rate constant $k_{1}$ (FF versus FP $p \leq 0.00$ I; FF versus MF $p \leq 0.00$ I; FP versus MF $p \leq$ $0.00 \mathrm{I}$ ), in equilibrium dissociation rate constant $k_{D}$ (FF versus $F P p \leq 0.00 \mathrm{I}$; FF versus $M F p \leq 0.05$; FP versus $M F p \leq 0.05$ ) and in the relative receptor affinity RRA (FF versus FP $\mathrm{p} \leq 0.00 \mathrm{I}$; $\mathrm{FF}$ versus $\mathrm{MF} \mathrm{P} \leq 0.05$; FP versus MF $\mathrm{P} \leq 0.0 \mathrm{I}$ ). No statistically significant difference between $\mathrm{FF}, \mathrm{MF}$ and $\mathrm{FP}$ was seen in the dissociation rate constant $\mathrm{k}_{-1}$ and the derived half life of the receptor complex $\mathrm{t}_{1 / 2}$. 


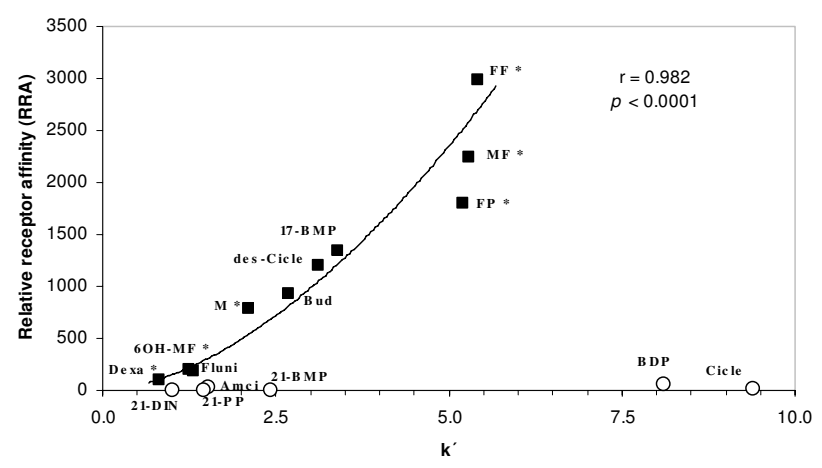

Figure 2

Relationship between the relative receptor affinities (RRA) of glucocorticoids and their lipophilicity expressed as relative retention times $\left(k^{\prime}\right)$. The reference glucocorticoid was dexamethasone for RRA and dexamethasone-2I-isonicotinate for $k^{\prime}$. Coefficient of correlation was $r=0.982$ and the correlation was statistically significant ( $p \leq 0.000 \mathrm{I})$. Symbols used: filled black squares: glucocorticoids without ester function at C2I open white circles: glucocorticoids esterified at C2I.* RRA determined in our own experiments, all other RRAs were obtained from [5, 16]. Abbreviations: Amcinonide (Amci), Dexamethasone (Dexa), Dexamethasone-2I-isonicotinate (2I-DIN), Flunisolide (Fluni), Fluticasone propionate (FP), Fluticasone furoate (FF), Mometasone (M), 6 $\beta$ Hydroxy-Mometasone furoate (6OH-MF), Mometasone furoate (MF), Budesonide (Bud), Ciclesonide (Cicle), desisobutyryl Ciclesonide (des-Cicle), BeclomethasoneI7,2I-dipropionate (BDP), Beclomethasone- I7-monopropionate (I7-BMP), Beclomethasone-2I-monopropionate (2IBMP), Prednisolone-2I-propionate (2I-PP).

\section{Stability of FF in freshly isolated human lung tissue}

The stability of FF in the presence in human lung tissue was monitored over a period of 24 hours at an incubation temperature of $37^{\circ} \mathrm{C}$ (Figure 3). The incubations were performed in the presence and absence of the esterase inhibitor diclorvos. Indications of instability of the compound are either decreased compound concentrations in the supernatant in the absence of dichlorvos and/or the appearance of new peaks in the HPLC chromatograms. The initial decrease of FF concentration indicated the binding to the lung tissue pieces. Over the incubation period, concentrations of FF in the tissue supernatant were slightly higher in the absence of dichlorvos. No new peaks were observed in the HPLC chromatograms. No statistically significant differences were revealed between concentrations of FF in the presence and absence of the esterase inhibitor diclorvos at any of the single time points. Thus, non-specific esterase-catalyzed hydrolysis of FF did not occur in the presence of human lung tissue.

The enzymatic integrity of the lung tissue was demonstrated in a simultaneously performed control experiment

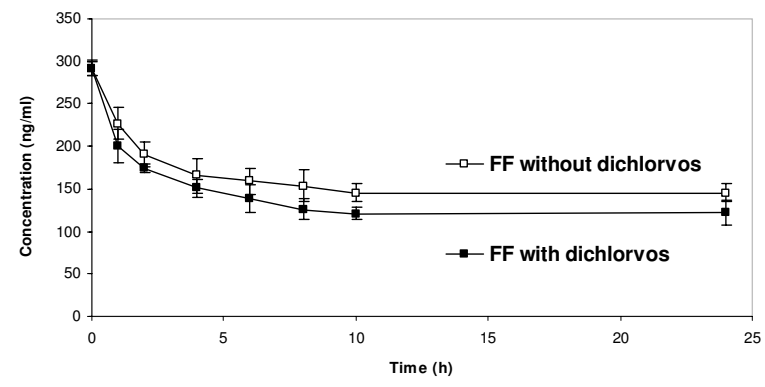

Figure 3

Stability of fluticasone furoate (FF) in human lung tissue suspensions of $37^{\circ} \mathrm{C}$ over 24 hours. Symbols represent the mean and mean deviation of the mean of four independent series of experiments. One incubation mixture contained the esterase inhibitor dichlorvos to determine a potential esterase mediated decomposition of the parent compound. No statistically significant differences between FF concentrations in the presence or absence of dichlorvos were observed at any of the analysed time points.

with beclomethasone-17,21-dipropionate (BDP). The results of these control experiments were identical to those described previously [3]. In the absence of dichlorvos BDP concentrations in the supernatant rapidly decreased and the main metabolite beclomethasone-17monopropionate (17-BMP) was detectable at high concentrations. Dichlorvos inhibited the decomposition of BDP and delayed the formation of 17-BMP up to 10 hours of incubation (data not shown).

\section{Lung tissue binding affinity of fluticasone furoate (FF)}

The binding affinity of FF in comparison with MF and FP to human lung tissue was determined in separate adsorption and desorption experiments. Control experiments for non-specific binding to incubation vials were performed in parallel with the respective glucocorticoid-containing buffer solutions under identical conditions. These control experiments revealed no non-specific binding of FF or FP to the glass incubation vials (Figure 4). A decrease in $\mathrm{MF}$ concentrations over $480 \mathrm{~min}$ at $37^{\circ} \mathrm{C}$ was paralleled by formation of the degradation product 9,11-epoxy MF as described earlier [3]. Thus, MF did not display non-specific binding to glass, but did show chemical instability.

Adsorption of FF to human lung tissue in vitro occurred rapidly and was complete after about $20 \mathrm{~min}$ (data not shown). After $60 \mathrm{~min}$ incubation with the glucocorticoidcontaining buffer at $37^{\circ} \mathrm{C}$ highest tissue binding was seen for FF $(4.18 \pm 0.16 \mathrm{ng} / \mathrm{mg})$ and this was statistically significantly higher compared to FP $(3.39 \pm 0.06 \mathrm{ng} / \mathrm{mg}$; $\mathrm{p} \leq$ $0.001)$ and $\mathrm{MF}(3.65 \pm 0.15 \mathrm{ng} / \mathrm{mg} ; \mathrm{p} \leq 0.01)$ (Figure 5 , left columns). FF also showed greater binding to human 
Control experiment without lung tissue

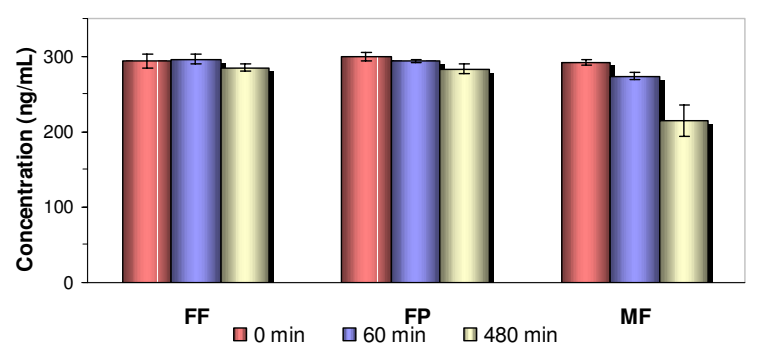

Figure 4

Control experiment for non-specific adsorption of glucocorticoids to incubation vials. The respective compounds were incubated in glass vials over $480 \mathrm{~min}$ at $37^{\circ} \mathrm{C}$. The concentration in the supernatant was monitored. The decrease in concentrations of mometasone furoate (MF) indicated the degradation process of the compound. No adsorption was seen for fluticasone propionate (FP) and fluticasone furoate (FF). The columns represent the mean and mean deviation of the mean from triplicate experiments.

nasal tissue compared with FP in a single experiment with tissue pooled from 3 donors (data not shown).

The desorption of the glucocorticoids from lung tissue into human plasma revealed differences between the compounds (Figure 5, right columns). After $60 \mathrm{~min}$ highest concentrations of FP $(1.55 \pm 0.13 \mathrm{ng} / \mathrm{mg})$ and FF $(1.21$ $\pm 0.23 \mathrm{ng} / \mathrm{mg}$ ) were still present in the tissue. Remaining concentrations of FP and FF were not statistically significantly different. As reported previously [3], MF was rapidly redistributed from the lung tissue into human plasma and consequently lowest concentrations of mometasone furoate were detected in the tissue $(0.57 \pm 0.15 \mathrm{ng} / \mathrm{mg})$. This was statistically significantly lower compared to FF ( $\mathrm{p}$ $\leq 0.01)$ and FP $(\mathrm{p} \leq 0.001)$.

\section{Discussion}

Fluticasone furoate (FF) is a newly developed glucocorticoid for topical application. In the present investigation we characterized the receptor binding kinetics and the binding affinity to human lung tissue of FF in comparison with other latest generation glucocorticoids. We found that FF exhibited the highest ever described relative receptor affinity (RRA) of a topical glucocorticoid. The RRA of FF $(2989 \pm 135)$ exceeds the receptor affinities of all currently used corticosteroids such as mometasone furoate $(\mathrm{MF} ; \mathrm{RRA}=2244 \pm 142)$, fluticasone propionate (FP; RRA $=1775 \pm 130)$, the active beclomethasone-17,21-dipropionate (BDP) metabolite beclomethasone-17-monopropionate (17-BMP; RRA = $1345 \pm 125)$, ciclesonide's active principle (des-Cicle; $R R A=1212$, rat receptor data) and
Compound retention in human lung tissue

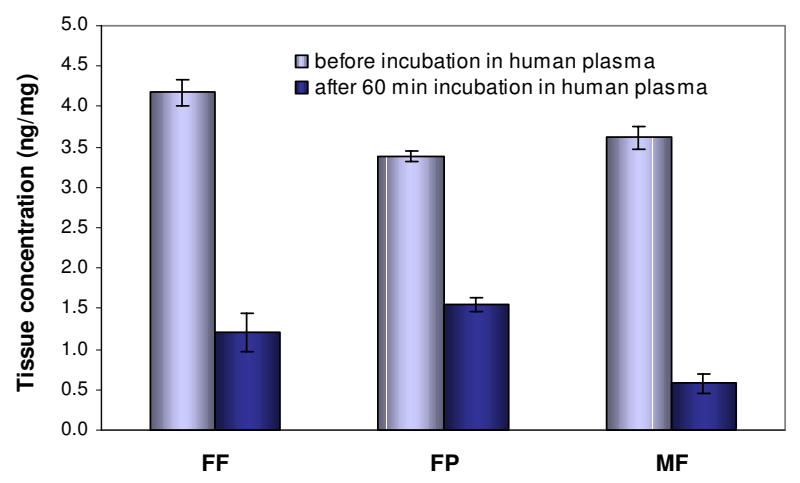

\section{Figure 5}

Comparison of concentrations of fluticasone furoate (FF), fluticasone propionate (FP) and mometasone furoate (MF) in human lung tissue. The columns represent the mean and mean deviation of the mean from four independent experiments. The left columns represent the compound concentration in tissue before incubation in human plasma. This tissue binding of FF was statistically significantly higher compared to FP $(p \leq 0.00 \mathrm{I})$ and MF $(\mathrm{p} \leq 0.0 \mathrm{I})$. The right columns display the glucocorticoid concentrations remaining in the lung tissue after one hour equilibration with human plasma at $37^{\circ} \mathrm{C}$. Remaining concentrations of FP and FF were not different while statistically significantly lower concentrations of MF were retained in the tissue compared to FF $(p \leq 0.0 \mathrm{I})$ and FP $(\mathrm{p} \leq 0.00 \mathrm{I})$.

budesonide ( RRA $=855)$. Together with the compound's high retention in human lung tissue $\mathrm{FF}$ incorporates attributes that are suitable for topical anti-inflammatory therapy.

The substitution pattern of the steroidal D-ring is important for the affinity to the glucocorticoid receptor as well as for receptor selectivity [17]. For example, the D-ring substitution confers on MF highly potent glucocorticoid receptor binding affinity $[4,18]$. We deduced that D-ring modifications of MF were so favourable for high affinity binding to the glucocorticoid receptor that metabolic hydroxylation at the $6 \beta$ position or loss of chlorine at the 9 position did not result in complete loss of ligand-binding properties.

One characteristic of the MF D-ring substitution pattern, the furoate moiety, is also present in FF. Consistent with the notion that the esterification of the $17 \alpha-\mathrm{OH}$ by furoylation augments affinity we a found remarkably high RRA for FF that exceeds the RRA of e.g. FP by more than $60 \%$. This result is supported by recent X-ray crystal structure data of FF co-crystallized with the glucocorticoid receptor [19]. These data show the $17 \alpha$-furoate ester fully 
occupying the lipophilic $17 \alpha$ pocket in the receptor and additional interactions with the receptor involving the 3keto, $11 \beta$-hydroxy and $17 \beta$-fluoromethylthioester groups of the fluticasone backbone.

We determined the affinity of FF to the human lung glucocorticoid receptor by separate analysis of the receptor association and dissociation kinetics. This method is more precise compared to competition assays, especially for high affinity glucocorticoids [1]. For FF we observed a very fast and extensive association with the receptor, with an association rate constant significantly higher than for any other glucocorticoid. In contrast, the dissociation rate constant was almost identical to that of FP. Thus, the difference between FF and FP is mainly based on the more rapid and preferential binding of FF to the receptor. This kinetic behaviour of FF confirms our previous insights into receptor binding characteristics of high-affinity glucocorticoids [1,3]. FP was the first glucocorticoid with receptor binding clearly distinct from other compounds. In comparison with other glucocorticoids it displayed both a more rapid association and prolonged dissociation from the receptor [1]. The receptor binding kinetics of MF disclosed a high association rate constant while its dissociation rate was almost comparable to FP [3]. Thus, further increase in receptor affinity for FF was related to an increase in the association rate constant which is now also established for this compound.

Interestingly, those glucocorticoids with the highest RRAs do not comply with the previously described linear relationship between lipophilicity and receptor affinity [5]. FF, MF and FP reveal clear differences in their RRA, but their lipophilicity expressed as their relative retention times at a reversed-phase HPLC column is less different than their receptor affinities. However, the correlation between lipophilicity of the active compound and its RRA is still highly significant, though not linear, if the high affinity glucocorticoids FF, FP and MF are included into the analysis. There are glucocorticoids with higher lipophilicity such as BDP and Cicle, but these compounds are pro-drugs with virtually no affinity to the receptor. Both drugs gain activity by ester cleavage in C21 position. Thereby, however, they lose their high lipophilicity.

Since FF is not a pro-drug, its receptor binding affinity and thus activity is associated with the entire molecule. The compound is expected to be stable in the therapeutic target tissue. This is not necessarily seen for all glucocorticoids. We and other research groups recently observed that MF is not stable in lung tissue or plasma and undergoes chemical degradation $[3,20,21]$. We now elucidated the stability of FF in human lung tissue and found no degradation or metabolism within $24 \mathrm{~h}$ at $37^{\circ} \mathrm{C}$. The esterase inhibitor dichlorvos was included in one of the incuba- tion mixtures in case of an enzyme-catalyzed hydrolysis of the $17 \alpha$ furoate moiety or of the $17 \beta$ S-fluoromethyl-carbothioate group. Neither did we determine the resulting metabolites or any other new peaks in the HPLC chromatograms nor did we observe lower FF concentrations in the tissue supernatant in the absence of dichlorvos. In the contrary, we found lower FF concentrations in the presence of the esterase inhibitor, though we do not have a clear explanation for this phenomenon. We conclude that there is no indication of instability or chemical modification of FF in the presence of enzymatically active human lung tissue.

Besides a high receptor binding affinity, a prolonged retention of the glucocorticoid in the lung tissue is a desired property. We compared the tissue binding behaviour of FF with FP and MF. After one hour equilibration of glucocorticoid-saturated lung tissue pieces with human plasma at $37^{\circ} \mathrm{C}$, we found highest concentrations of FF and FP compared to MF remaining in the tissue. Obviously, these compounds have the most favourable tissue affinity and it should be expected that the distribution of these glucocorticoids from lung tissue into systemic circulation is slow in vivo. Clinical data confirm this for FP [22].

To conclude, we have characterized the novel glucocorticoid fluticasone furoate. Its relative receptor binding affinity exceeds the RRAs of all other currently clinically used glucocorticoids. Based on the tissue binding experiments a high retention of fluticasone furoate in human lung tissue is expected. These advantageous binding attributes may contribute to a highly efficacious profile for FF as a topical treatment for inflammatory disorders of the respiratory tract.

\section{Competing interests}

Parts of this study were supported by a research grant of GlaxoSmithKline. This funding had no role in the collection, analysis and interpretation of data or in the writing of the manuscript.

\section{Authors' contributions}

A.V. designed, carried out and analysed all the experiments and contributed to writing the manuscript.

P.H. conceived of the study, participated in the study design, performed the statistical analysis and drafted the manuscript.

All authors read and approved the final manuscript.

\section{Acknowledgements}

We would like to thank Prof. Knut Baumann of the Technical University of Braunschweig for helpful discussions and advice on statistics and Roswitha Skrabala for expert technical assistance. 


\section{References}

I. Högger P, Rohdewald P: Binding kinetics of fluticasone propionate to the human glucocorticoid receptor. Steroids 1994, 59:597-602.

2. Högger P: Comparison of the tissue affinity of glucocorticoids to human lung, nasal and skin tissue in vitro. Arzneimittelforschung 200I, 5 I:825-83I.

3. Valotis A, Neukam K, Ehlert O, Högger P: Human receptor kinetics, tissue binding affinity and stability of mometasone furoate. J Pharm Sci 2004, 93:1337-1350.

4. Valotis A, Högger P: Significant receptor affinities of metabolites and a degradation product of mometasone furoate. Respir Res 2004, 5:7.

5. Würthwein G, Rehder S, Rohdewald P: Lipophilicity and receptor affinity of glucocorticoids. Pharm Ztg Wiss 1992, 4: I6I-I67.

6. Lowry OH, Rosebrough NJ, Farr AL, Randell RJ: Protein measurement with the folin phenol reagent. J Biol Chem 195I, I 93:265.

7. Toft $D$, Gorski J: A receptor molecule for estrogens: isolation from the rat uterus and preliminary characterization. Proc Natl Acad Sci U S A 1966, 55:1574-I58I.

8. Rodbard D, Rayford PL, Cooper JA, Ross GT: Statistical quality control of radioimmunoassays. J Clin Endocrinol Metab 1968, 28: $1412-1418$.

9. Baxter JD, Tomkins GM: Specific cytoplasmic glucocorticoid hormone receptors in hepatoma tissue culture cells. Proc Natl Acad Sci U S A 197I, 68:932-937.

10. Scatchard G: The attraction of proteins for small molecules. Ann N Y Acad Sci 1949, 5 I:660-672.

I I. David HA, Hartley HO, Pearson ES: The distribution of the ratio, in a single normal sample of the range to standard deviation. Biometrika 1954, 41:482-493.

12. Pearson ES, Stephens MA: The ration of range to standard deviation in the same normal sample. Biometrika I964, 5 I:484-487.

13. Leo A, Hansch C, Jow PY: Dependence of hydrophobicity of apolar molecules on their molecular volume. J Med Chem |976, 19:6||-615.

14. Caron JC, Shroot B: Determination of partition coefficients of glucocorticosteroids by high-performance liquid chromatography. J Pharm Sci 1984, 73:1703-1706.

15. Würthwein G, Rohdewald P: Activation of beclomethasone dipropionate by hydrolysis to beclomethasone- I 7-monopropionate. Biopharm Drug Dispos 1990, I I:38I-394.

16. Stoeck M, Riedel R, Hochhaus G, Hafner D, Masso JM, Schmidt B, Hatzelmann A, Marx D, Bundschuh DS: In vitro and in vivo antiinflammatory activity of the new glucocorticoid ciclesonide. J Pharmacol Exp Ther 2004, 309:249-258.

17. Högger P: Current concepts for optimizing the therapeutic index of glucocorticoid receptor ligands for oral and inhalative use: basic considerations and clinical reality. Curr Med Chem Anti-Inflamm Anti-Allergy Agents 2003, 2:395-408.

18. Isogai M, Shimizu H, Esumi Y, Terasawa T, Okada T, Sugeno K: Binding affinities of mometasone furoate and related compounds including its metabolites for the glucocorticoid receptor of rat skin tissue. J Steroid Biochem Mol Biol 1993, 44: |4|-|45.

19. Biggadike K, Bledsoe R, Hassell A, S. H, Shewchuk L: GW685698X - enhanced affinity for the glucocorticoid receptor: receptor crystal structure and route of metabolic inactivation. $X X V$ Congress of the European Academy of Allergology and Clinical Immunology; I0-I 4 June; Vienna 2006.

20. Teng XW, Cutler DJ, Davies NM: Mometasone furoate degradation and metabolism in human biological fluids and tissues. Biopharm Drug Dispos 2003, 24(8):321-333.

21. Sahasranaman S, Issar M, Toth G, Horvath G, Hochhaus G: Characterization of degradation products of mometasone furoate. Pharmazie 2004, 59:367-373.

22. Esmailpour N, Högger P, Rabe KF, Heitmann U, Nakashima M, Rohdewald $P$ : Distribution of inhaled fluticasone propionate between human lung tissue and serum in vivo. Eur Respir J I997, I0(7): |496-1499.

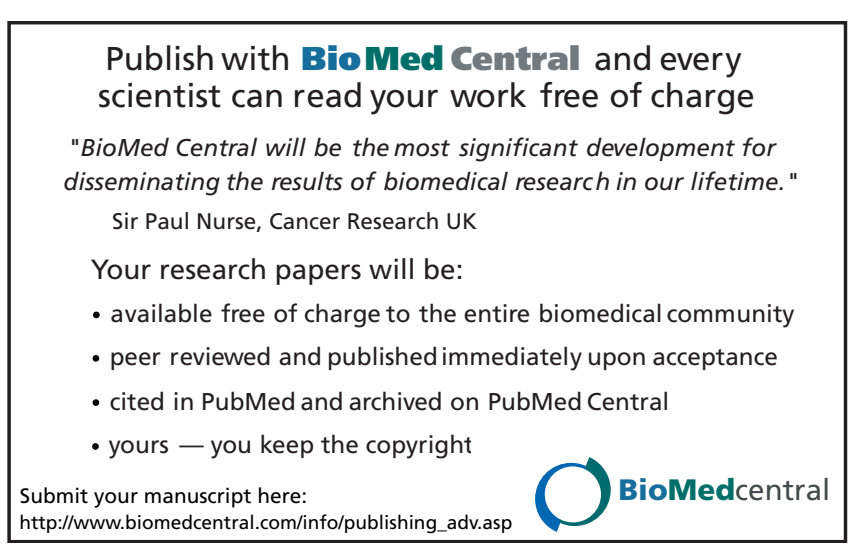

